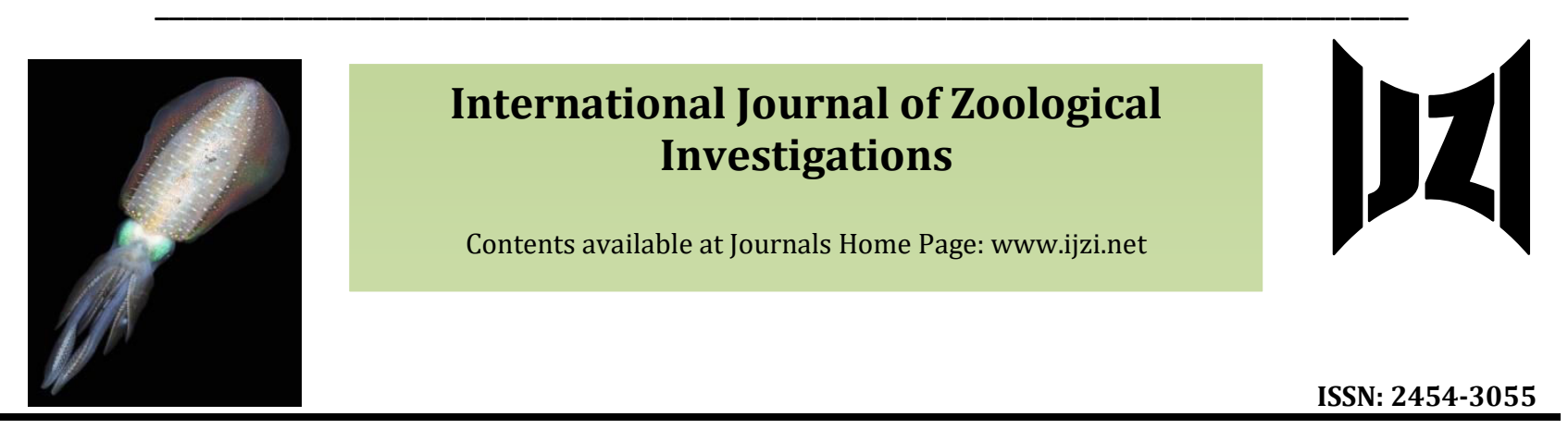

\title{
Fish Diseases Analysis Used as Bioindicators for Water Quality and its Importance for Environmental Monitoring
}

\author{
Fábio Flores Lopes \\ Department of Biological Sciences, Universidade Estadual de Santa Cruz (State University of Santa Cruz) - UESC, Rodovia Ilhéus- \\ Itabuna, km 16, 45650-000, Ilhéus, BA, Brazil
}

Received: $13^{\text {th }}$ November, 2020

Accepted: $14^{\text {th }}$ January, 2021

Published online: $5^{\text {th }}$ February, 2021

https://doi.org/10.33745/ijzi.2021.v07i01.001

\begin{abstract}
Species of fish are important vehicles for the transfer of contaminants to human populations, and may show the potential exposure to pollutants. They have been used as representative taxocenosis of aquatic ecosystem biotic community and as a environmental quality assessment tool. Its use in environmental monitoring has several advantages because they are directly associated with agent stressors. The objective of this study was to relate the histopathological changes observed and to verify the significance of histological analysis as a method of histopathological evaluation in studies carried out in the area. The study also includes the importance of such type of analysis in environmental change and to efficiently measure the degree of exposure in aquatic organisms to chemical contaminant.
\end{abstract}

For histological analysis the animals were fixed in $10 \%$ formaldehyde and then decalcified, dehydrated with ethyl alcohol for impregnation and paraffin embedding and cut at 5-7 $\mu \mathrm{m}$. The sections were stained with Hematoxylin and Eosin. Several types of alterations were observed in the specimens, some of them macroscopically visible. The occurrence of this type of alteration is evidence of the presence of pollutants and/or degraded habitats of the environments and the analysis of the spatial and temporal variation of their frequency of occurrence in these environments represents an important source of evaluation and monitoring of water quality in these environments.

Keywords: Histopathological alterations, Pollutants, Avaliation

Citation: Fábio Flores Lopes: Fish diseases analysis used as bioindicators for water quality and its importance for environmental monitoring. Intern. J. Zool. Invest. 7 (1): 01-16, 2021.

https://doi.org/10.33745/ijzi.2021.v07i01.001

\section{Introduction}

Disturbances caused by environmental contaminants to fishes affect their biological characteristics and increase vulnerability to unfavourable environmental factors. Vasanthi et al. (2013) reported that the presence of contaminants usually appear in the 
environment as very complex mixtures that can cause interactive effects on the biota. It is impossible to evaluate these contaminants only by means of chemical analysis. According to Teh et al. (1997), histopathological analysis has already been tested and proposed as an efficient and sensitive tool to monitor fish health and environmental pollution in natural water bodies.

Several analysis methods were considered as reliable to evaluate the biological response towards environmental risk so that preventive measures can be taken (Dalzochio et al., 2016). Gharred et al. (2015) and Morado et al. (2017) stated that biomarkers are measurements within an organism that respond to environmental effects and are used as tools in bio-assessment programs since they reflect physiological changes induced by exposure to pollutants. Studies on fish biomarkers are of great significance as they can help to evaluate organ alterations, enzymatic responses, and histological changes when exposed to polluted aquatic environment (Bassey, 2019). The use of biomarkers for biomonitoring environmental quality in aquatic ecosystem had improved a great deal and promising tool of interest caused by its economical method, adequate in the assessment of overall toxicities of complex mixtures and measurement precision (Bassey, 2019).

The use of species as biomarkers with the purpose of biomonitoring natural aquatic systems is necessary to efficiently measure the degree of exposure in aquatic organisms to chemical contaminants, although its largescale application is rare (Sureda et al., 2011). The genetic, biochemical, behavioral and morphological responses represent useful biomarkers in environmental biomonitoring and were considered important factors with their importance highlighted by Ballesteros et al. (2009).

The use of fish in environmental monitoring studies has several advantages (Jenkins (2004), as they are directly associated with the sediment and water column, have poor mobility and exhibit some physiological mechanisms of biological responses. According to Karr (1981), fish communities can provide important information about the aquatic environment and are therefore excellent indicators of environmental quality. Fish serve as bioindicators of pollution due to a great deal of response and sensitivity to changes in the aquatic environment, which plays an increasingly important role in biomonitoring of environmental pollution (Bassey, 2019).

According to Thophon et al. (2003), Jenkins (2004), Gharred et al. (2015) and Morado et al. (2017), a biomarker has the advantage to elucidate the stress level through bioassay on the organism at various stages from biomolecular and histological to physiological alterations induced by environmental stressors. Chronic and sublethal effects have been widely used as biomarkers in the health evaluation of fish exposed to contaminants, and are important as indicators of exposure (Flores-Lopes et al., 2019). Histopathology is a great tool to assess the degree of pollution. Chavan and Muley (2014) stated that the study of histopathology is of prime importance in the diagnosis, etiology and prevention of disease.

Few studies have used fish species as a representative taxocenosis of the aquatic ecosystem biotic community and as an environmental quality assessment tool. 
Bassey (2019) reported that fish biomarkers are of great significance as they can help to evaluate organ alterations, enzymatic responses and histological changes when exposed to polluted aquatic environment. According to Cantanhêde et al. (2014), histopathological changes in fish indicate that individuals have developed defense mechanisms against the action of stressors present in the water and against possible imbalances associated with low quality of the environment. For them, currently, the appearance of individuals with some type of anomaly has been widely used in environmental monitoring programs and histological changes in fish tissues are considered as biomarkers (Cantanhêde et al., 2014) . The occurrence of various types of anomalies in fish can be used as a parameter for assessing environmental quality.

The objective of this study was to review the published reports in which the different types of changes observed using histopathological and ultrastructural analysis after exposure to chemical substances present in the environments. This study also aimed to verify the importance of the results obtained by histopathological analysis as a way of verifying the occurrence of different types of changes caused by different stressors.

\section{Materials and Methods}

This review was conducted with the aim of considering the results obtained in various studies and verifying the significance of histological analysis as an important method in the evaluation of environmental quality, through the occurrence of different types of changes caused by the presence of several types of chemical substances that cause several tissue modifications and are called "Estressoeres Agents".

The method used in all reports was histological preparations of biological materials collected at several study points. The animals were anesthetized by using MS 222 (Ethyl 3-aminobenzoate methanesulfonate salt). Then, the animals were fixed with $10 \%$ formaldehyde for a period of one week. After this process, the animals were preserved in $70 \%$ alcohol. Selected specimens were deposited in Scientific Collections, Museums or Research Laboratories - (UESC).

To prepare the slides for histological studies, the material was decalcified, dehydrated and impregnated with paraffin. Subsequently, the material was cut at 5 to 7 $\mu \mathrm{m}$ and stained wih Hematoxylin and eosin (HE).

\section{Results}

The observations of earlier studies have been mentioned here. These studies mainly focus on the histological alterations in various tissues after exposure to some stressors chemical or parasites. Flores-Lopes et al. (2001) reported the occurrence of epidermal tumors in specimens of Rineloricaria strigilata related to the abnormal and excessive proliferation of epithelial and connective tissue cells associated with hypertrophy (Figs. 1A, B). The histological analysis allowed a macroscopic view of the bone plates and odontodes covering the body, making it possible to perceive changes in the forming tissues. Histological analysis demonstrated the presence of alterations in the epithelial and connective tissue of this structure. (Figs. 1C, D). 

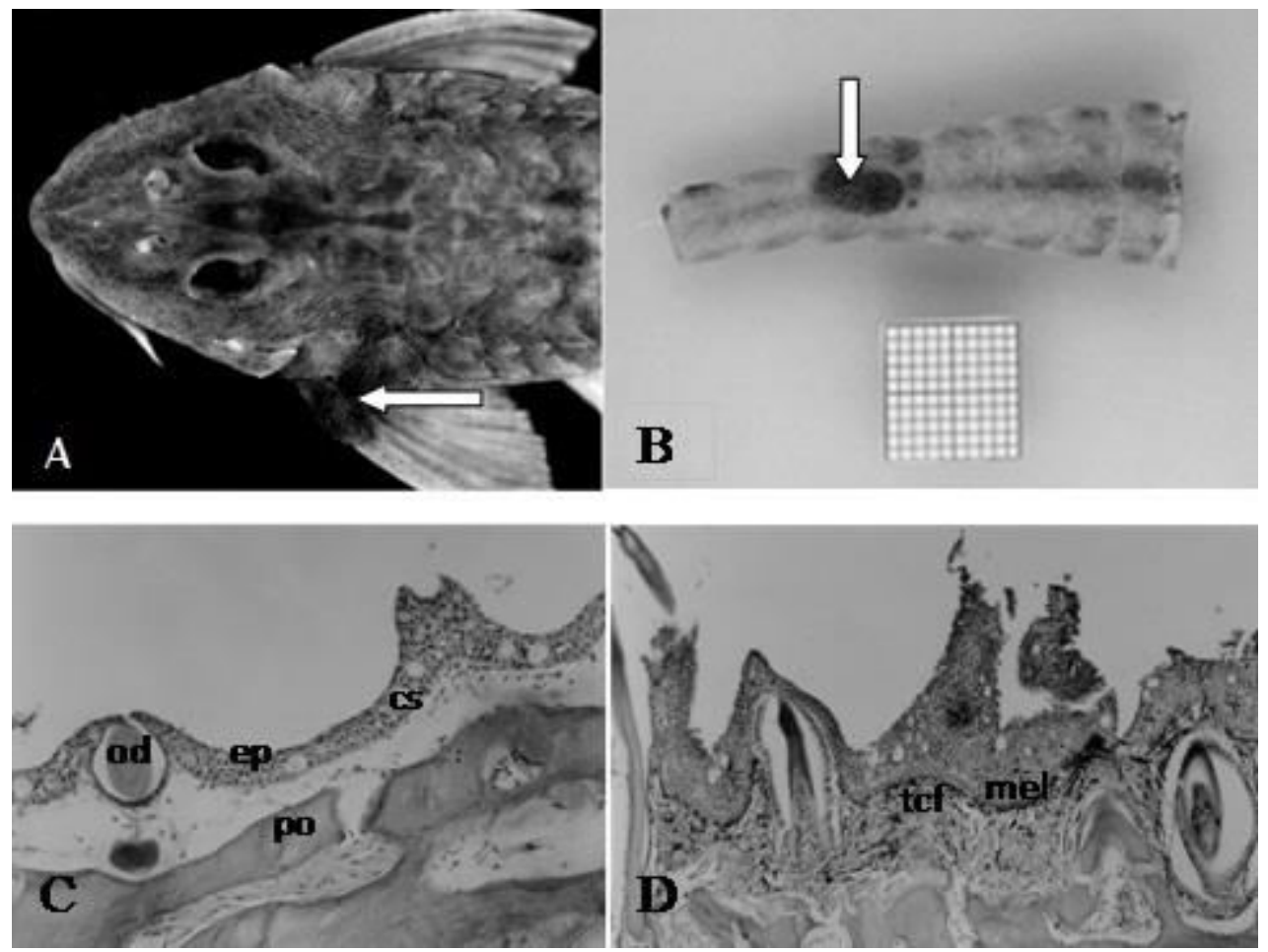

Fig. 1: Tumors observed in specimens of the species Rineloricaria strigilata: (A) - In the pectoral fin; (B) -In the caudal peduncle; ( $C$ and D) -- Histological section of bone plates. ep - Epidermis; cs - mucus-secreting cells; mel - Melanin layer; tcf - Loose connective tissue; o - Bone plates; od - Odontodes (Flores- Lopes et al., 2001).

Flores-Lopes (2000) and Flores-Lopes et al. (2001) showed that the observed changes caused the occurrence of bone plates in Rineloricaria strigilata and were associated with the prevalence of infection by digenetic trematode parasites, probably belonging to the strigeatoid order. Electron microscopy scans showed total disorientation of odontodes in the region of the tumors (Figs. 2A, B, C).

Few authors observed that most of the parasites were located in the spine and the metacercariae appeared surrounded by layers of blood cells such as leukocytes (lymphocytes), macrophages and connective tissue. Flores-Lopes et al. (2001), FloresLopes and Reuss-Strenzel (2011), Flores-
Lopes and Thomaz (2011) and Flores-Lopes (2014), while carrying out studies on Guaíba lake, observed a high frequency of specimens of Astyanax alburnus with changes in their bodies. Malabarba et al. $(1996,1997)$ noticed morphological deformity in the body called kypholordosis (Fig. 2D).

Flores-Lopes and Thomaz (2011) reported that fish gills are organs used in environmental monitoring programs. The histopathological modifications observed in the species Cyanocharax alburnus were alteration of primary lamella, alteration of the epithelium structure, cell vacuolization, hyperplasia of the primary lamella epithelium, and severe lifting of filamentar and lamellar epithelium (Figs. 3A, B). In gill, modification of 


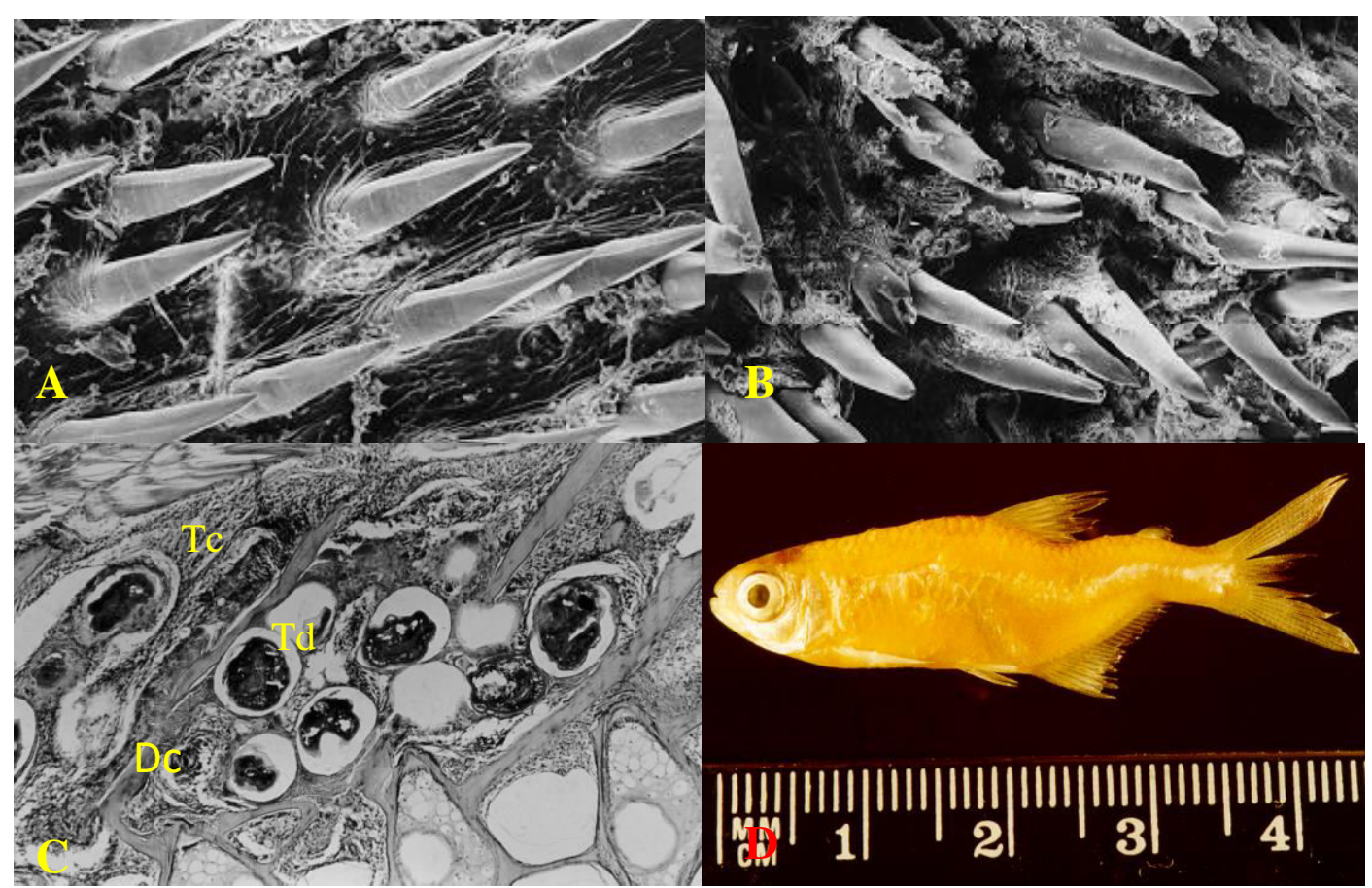

Fig. 2: Bone plates of the species Rineloricaria strigilata. (A) - Plaque with normal position of odontodes, (B) Plaque with disorganized odontodes forming a tumor in the epithelial tissue (Flores-Lopes et al., 2001), (C) Digenetic trematodes in the spine of Astyanax alburnus, (D) - Astyanax alburnus specimen with kypholordosis. Td - Trematoda-Digenea; Dc - Cell degeneration; Tc - Connective tissue (Flores-Lopes et al., 2001; Flores-Lopes, 2000).

the primary lamella can be observed, such as the cyst similarity with parasitic protozoa (Fig. 3B).

The secondary lamellae showed hypertrophy of the secretory cells, epithelial lifting, alteration of the structure, the presence of pyknotic nucleus in the Pillar cells, infiltration of the immune system cells and occurrence of aneurysms of various sizes in some secondary lamellae (Figs. 3B, C). , the occurrence of hyperplasia was verified, demonstrating the severity of the filamentary epithelial tissue, of the blood vessels, hyperplasia of the epithelial cells and cells of the immune system (Fig. 3C). Flores-Lopes and Thomaz (2011) observed the presence of several secondary lamella aneurysms (Fig. 3D).

In Parablennius incognitus, Gharred et al. (2015) observed that hepatic tissue from the contaminated site had various alterations, such as hypertrophy of hepatocytes, and congestion and dilation of the central vein of the Hepatic Portal System. The gills of Mugil celphalus showed aneurysm or nodule formation in the secondary lamellae, and hypertrophy was observed with the enlargement of the tissues (Vasanthi et al., 2013).

The ultra-thin section of the fish gills belonging to the control group showed a smooth surface topography and organized 
arrangements of primary and secondary lamellae with uniform interlamellar space.
Fish liver showed hepatocyte vacuolization and proliferation of fibroblast. Hepatocellular
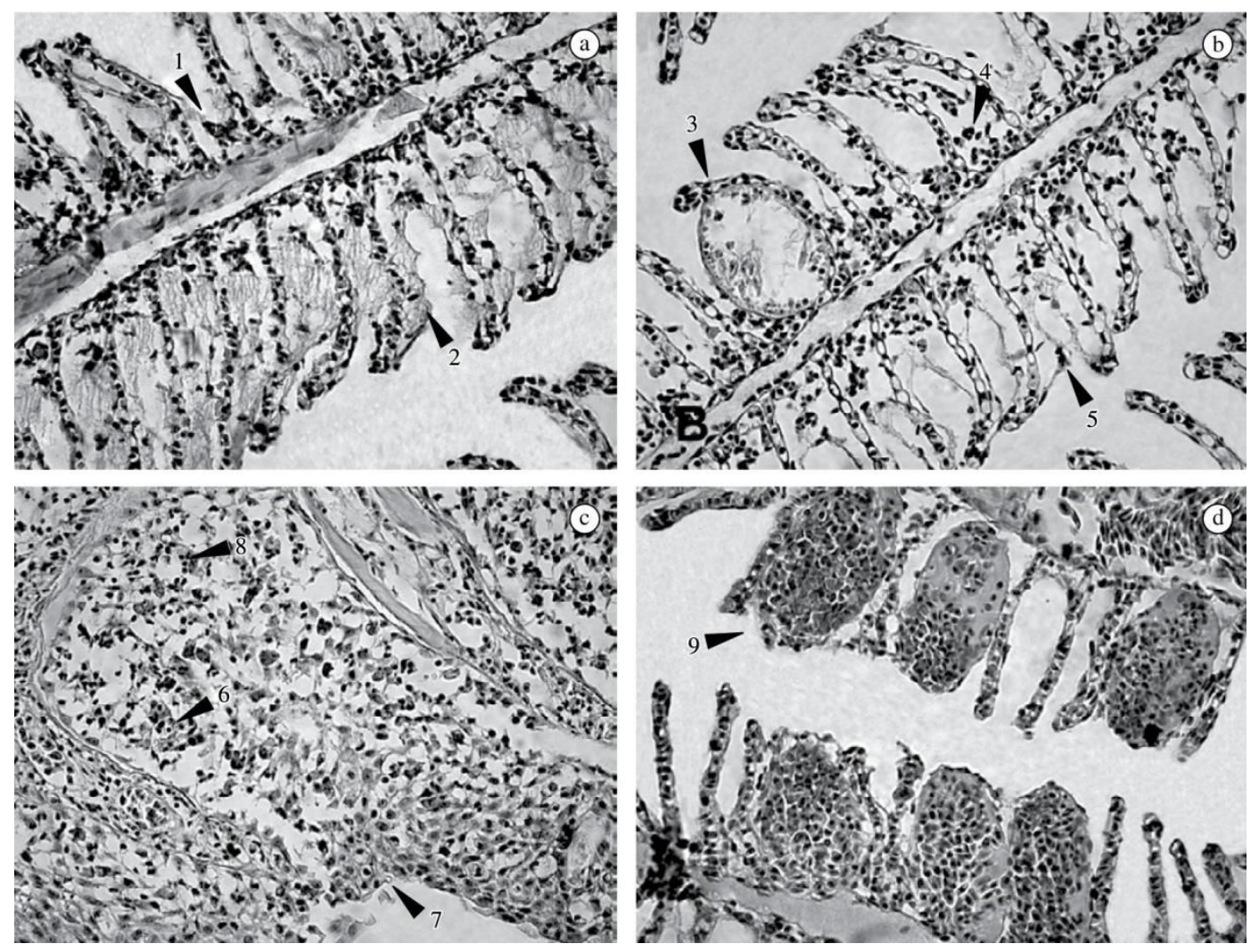

Fig. 3: Gills of Cyanocharax alburnus. (a) 1- alteration of primary lamella structure; 2- secretion of mucus; 400X; (b) 3- cyst with parasitic protozoans; 4- concentration of epithelial cells; 5- epithelial lifting of secondary lamella; 400X; (c) 6- Hyperplasia, blood vessel, 7- hyperplasia of epithelial cells, 8- cells of immune system; 400X; (d) 9- aneurysm of secondary lamella; 400X. (Flores-Lopes and Thomaz, 2011).

necrosis was obvious in the hepatocytes, showed organelle with classical morphological aspects including nucleus, mitochondria, lipid granules and rough endoplasmic reticulum.

Flores-Lopes and Thomaz (2011) demonstrated histopathological changes in the gill epithelium of the Astyanax fasciatus, such as vacuolation and hyperplasia of the primary lamella epithelium, in addition to hypertrophy and hyperplasia of mucussecreting and other cells (Fig. 4B). Histopathological alterations in the epithelium structure were observed -- vacuolization and hyperplasia, hypertrophy, epithelial lifting, pyknotic nucleus, secretion of mucus, infiltration, aneurysms (Fig. 4 C). Flores-Lopes and Thomaz (2011) stated that the individuals had a black spot disease infestation and the histological analysis showed that the agent causing this disease was a digenetic trematode (probably Diplostomatidae family) during the metacercariae stage. This trematode settles below the stratified epithelial tissue or beneath the dense connective tissue located just below the epithelium and above the muscle (Fig. 4 D).

In Acipenser ruthenus, Poleksic et al. (2010) observed alterations in the gills such as distended tips of the secondary lamellae, 
and a focal hyperplasia and hypertrophy of the respiratory epithelium. In the liver, they observed fibrosis, congestion of sinusoids, vasodilatation, hepatocyte cloudy swelling and melanomacrophage centers. In a study that aimed to assess the toxic potential of
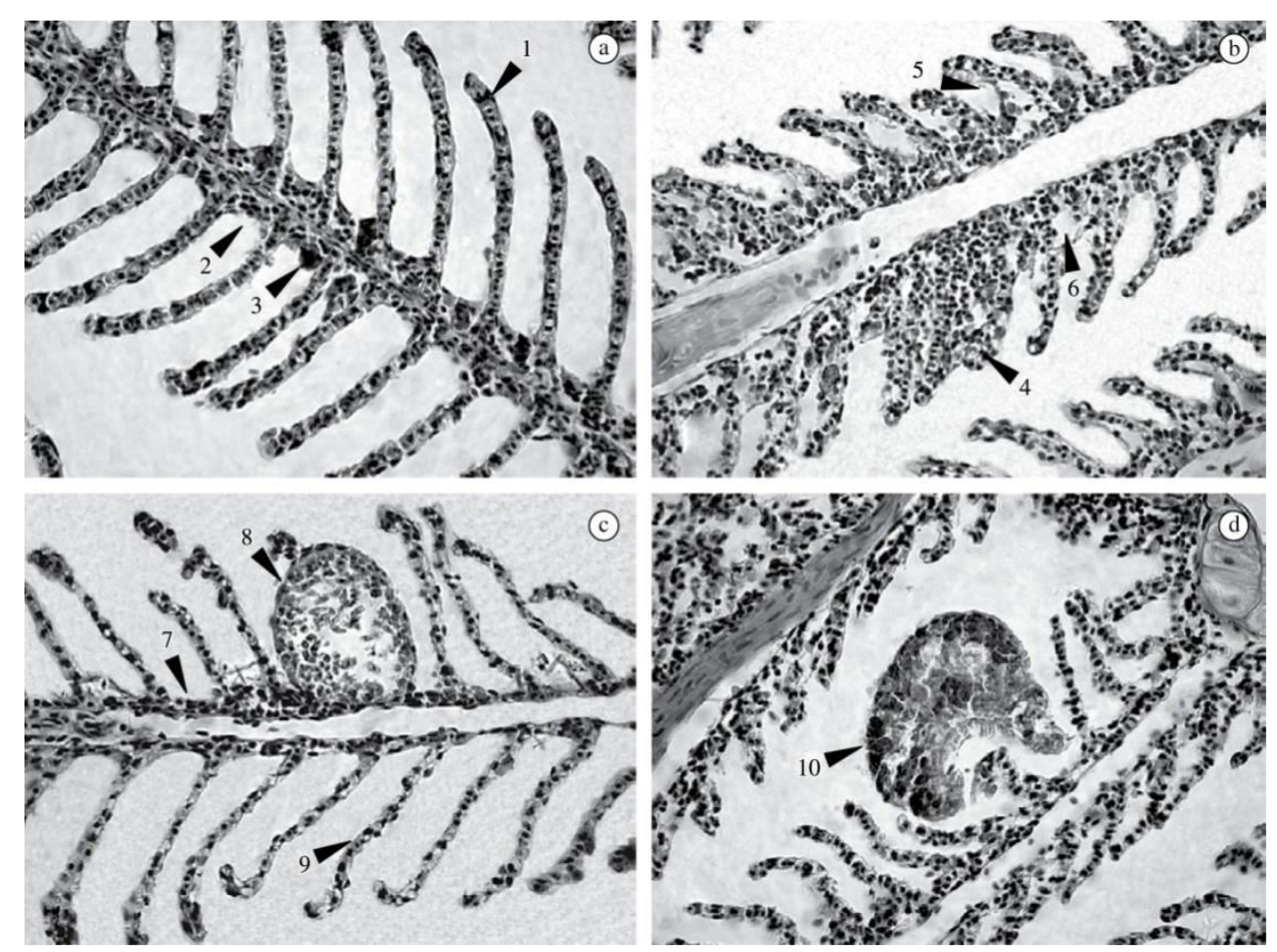

Fig. 4: Gill of Astyanax fasciatus. (a) Normal Gill (1 - secondary lamella; 2 - primary lamella; 3 - chloride cells; 400X); (b-d) gills with alterations; (b) 4 - fusion of secondary lamella; 5 - epithelium detachment; 6 - vacuolization; 400X; (c) 7 - alteration of primary filament structure; 8 - cyst with parasitic protozoans; 9 - alteration of secondary lamella structure; 400X; $\quad$ (d) 10 - monogenetic parasite; 400X (Flores-Lopes and Thomaz, 2011).

cadmium in Oreochromis niloticus, Paulo et al. (2020) found the presence of death cell areas in the hepatic parenchyma, characterizing an area of necrosis with degenerating pancreas and a large number of atrophied cells with the strongly condensed chromatin. These authors observed a high frequency of moderate and severe lesions, classifying the organ as having irreparable structural damage. Flores-Lopes et al. (2020) suggested that high amount of chemicals, such as $\mathrm{Mg}^{+2}, \mathrm{Ca}^{2+}, \mathrm{K}^{+}, \mathrm{Na}^{+}$, etc., probably caused histological changes in individuals.The gill tissue showed histological alterations like lifting of the respiratory epithelium, hyperplasia of the lamellar epithelium, parasites, and aneurysm.
Flores-Lopes et al. $(2019,2020)$ reported that the most frequent changes were the occurrence of leukocyte infiltration, irregular hepatocyte form, cell degeneration with cytoplasmic vacuolization and more than one vacuole per cell. When analyzing specimens of Oncorhynchus mykiss, Banaee et al. (2013) reported that histopathological analysis had important alterations in liver including necrosis, cytoskeleton disarray, changes in nuclear shape and heterochromatin distribution as well as intense damages in Disse's space between hepatocytes and sinusoid vessels, increased vacuolization of the endothelial cells and morphological derangement. 
In order to assess the environmental impact of some chemical components in the liver of Tilapia rendalli, Flores-Lopes et al. (2020) used histological and ultrastructural

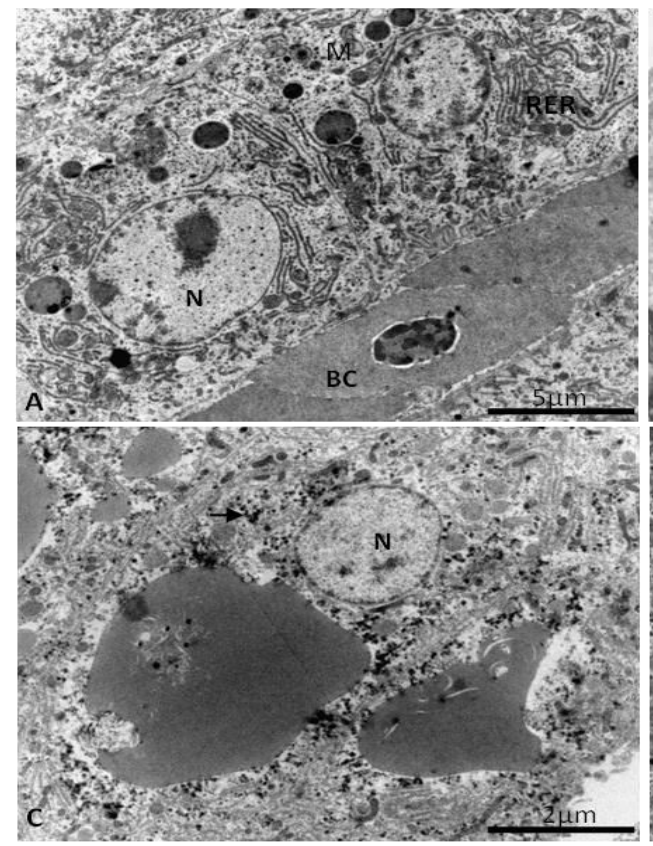

analysis to demonstrate different types of alterations observed in the organs and cells that form these tissues. These authors found injuries in the exocrine pancreas,

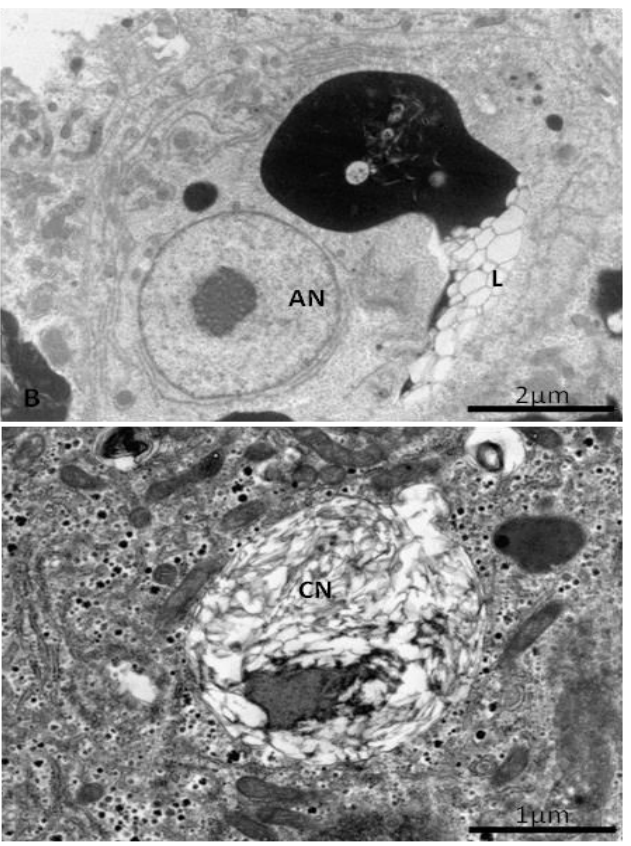

Fig. 5: Electron microscopy of Tilapia rendalli liver. N - Nucleus, BC - Blood cell, M - Mitochondria, RER - Rough endoplasmic reticulum, AN - Apoptotic nucleus, L - Lipids, CN - Celular necrosis and glycogen (arrow) (FloresLopes et al., 2020).

rectilineation of blood vessels, pyknotic nuclei, cytoplasmic degeneration, irregular hepatocytes, nuclei in the lateral position, cytoplasmic vacuolation, leukocyte infiltration, nuclear hypertrophy and cellular and focal necrosis (Fig. 5 A). Ultrastructurally an increase in lipid droplets and secretory granules, cell necrosis, nuclei in the apoptotic process (Fig. 5 B), organelles with undefined architecture, celular necrosis and glycogen (Fig. $5 \mathrm{C}$ ), and large zymogen granules composed of very electron-dense material were noticed (Fig. 5 D).

Malabarba et al. (1996) and Flores-Lopes and Thomaz (2011) observed several histopathological alterations, such as vacuolation and hyperplasia of the primary lamellar epithelium, high incidence of bone plate epidermal tumors and an occasional occurrence of tumors. These authors demonstrated that changes in the gills of these individuals were affected by the action of various stressors. Flores-Lopes et al. (2001) described the presence of macroscopic alterations, called neoplasms or neoplasias, a growth disorder, characterized mainly by an incessant, abnormal and excessive cell proliferation. Alterations such as necrosis, hyperplasia, hypertrophy, rupture of the branchial epithelium, mucus hypersecretion and lamellar fusion were noticed by FloresLopes et al. (2005), who pointed out that they were more frequent in fish gills exposed to toxicants, and some of these lesions are found more frequently in places contaminated with heavy metals than with other toxic components. Flores-Lopes and Malabarba 
(2007) pointed out that organ damage, such as tumors or neoplasms seems to be related to the presence of pollutants.

\section{Discussion}

Previous studies reported that exposure of fish to pollutants (agricultural, industrial and sewage) resulted in several pathological alterations in different tissues of fish (Abbas and Ali, 2007). Several of these studies observerd alterations in different organs and forming tissues.They demonstrate the effects caused by several chemical compounds (stressors), and classify them as eliminated agents, since they cause several types of changes in the tissues.

According to Kinne (1984) the term stress means forces (i.e. variations in temperature and salinity, oxygen availability, impact of disease-causing agents, social dominance) that act on an organism or its parts that are significant enough to interfere with its normal functions. Such forces can produce specific and non-specific responses. Wedemeyer and McLeay (1981) emphasized that stress is best defined as the effect of any environmental change or force that extends homeostatic or stabilization processes beyond their normal limit at any level of biological organization.

The occurrence of various types of changes, according to Flores-Lopes and Malabarba (2007) and Paulo et al. (2012), demonstrates that the water quality of the environments are undergoing important changes in its constitution, being greatly influenced by the presence of several types of polluting substances that will cause several alterations in the diverse species. These authors show the continuous action of stressors, since the histological changes only begin to appear after some time of exposure to the polluting agent.

Environmental change, usually of anthropogenic origin, causes disturbances of varying degree of severity, such as profound changes in the physical and chemical characteristics of aquatic environments, which contributes to modify the evolution of natural systems (Boudou and Ribeyre, 1989; Schulz and Martins-Junior, 2001). Sindermann (1990), Adams (1990) and Thomas (1990) commented that stress represents the sum of morphological, physiological, biochemical and behavioral changes in individuals, resulting from the action of stressors that somehow alter the structure of the population. The changes observed in histological investigations of several studies, with different species, have demonstrated the action of stressors and the effects caused by these substances on the analyzed organs and tissues. According to Sindermann (1990), much of what we call pathology or disease is a consequence of environmental stressor action, mainly because many pollutants are environmental chemical stressors. The appearance of several types of alterations is probably related to the presence of various stressor agents in the studied environments.

Adams (1990) and Thomas (1990) stated that stress effects on fish health are particularly important when damage to health tends to reduce survival, growth, and reproductive success, therefore reducing the intrinsic rate of population growth. Thus, such organisms become predisposed to disease, with a reduced fish's ability to tolerate subsequent stresses such as salinity fluctuation, temperature, $\mathrm{pH}$, dissolved oxygen, parasite infection and natural predators. Any environmental factor that is 
not optimal can act as a stressor for fish, which, if extreme or prolonged enough, can affect an individual's survival (Sindermann, 1990).

Few studies using biological monitoring with fish have been conducted in various environments, especially using native species. $\mathrm{Au}$ et al. (1999) and Kim et al. (2001) pointed out that cytological and histopathological changes in fish tissues are useful biomarkers of the exposure effect to toxic substances, which reflects priority changes in biochemical and/or physiological functions. Histopathological examination has been recognized by several authors as a valuable tool for assessing stressful environmental impacts on fish populations (The et al., 1997; Oliveira Ribeiro et al., 2002).

Histological biomarkers provide a powerful tool for detecting and characterizing the biological endpoint of toxic substances and exposure to carcinogens. Moore and Simpson (1992) reported that methods for identifying adverse changes induced by toxic substances should initially focus on organs such as the liver and kidney, as these organs have the function of metabolizing and eliminating toxic substances. Histological analysis represents an efficient method for detecting effects of irritants, especially some chronic ones, on various tissues and organs. Bernet et al. (1999) and Paulo et al. (2020) demonstrated the significance and importance of using the histopathological analysis in order to evaluate the occurrence of various types of changes in different species. Bassey (2019) stated that histology is a useful technique towards the assessment of toxic substances in aquatic organisms from polluted ecosystems.
Flores-Lopes et al. (2020) sugested the use of different methods (physico-chemical, histological and ultrastructural) were efficient to evaluate the environmental quality. Facey et al. (2005) suggested that physiological stress in fish population decreased with reduction in exposure to pollutants and Paulo et al. (2012) observed that fish tissue alterations are reliable and efficient tools to detect and monitor environments that are influenced by anthropogenic activities.

Malins (1989) concluded that histopathological alterations are almost exclusively associated with tissue changes, and occur mainly in fish from areas close to high demographic densities and/or that have relatively high degree of sediment contamination. According to McCain et al. (1988), histopathological conditions tend to reflect long-term chronic effects and provide small indication of more acute effects that may be happening in an ecosystem. Moore (1985) pointed out that pollutant-induced cellular responses should, in theory, provide faster and highly sensitive indicators of environmental impact.

Water pollution induces pathological changes in fish (Bernet et al., 1999) and these modifications range from biochemical alterations in a single cell to changes in the entire population. Gonzalez et al. (1993) and Walters and Plumb (1980) have shown that physicochemical or biotic modifications in the aquatic environment induce injury to fish and these variations in water chemistry can be directly lethal to fish, and the sub-lethal damages can sufficiently stress the fish, predisposing them to infectious disease.

Möller (1985) has shown that attention to the impact of pollution on fish health has 
intensified as pollutants can cause diseases that increase mortality or decrease the commercialization of valuable species, and a disease can serve as a monitor for pollution purposes. Bergman (1985) cites the following changes: 1- genetic mutations, 2- changes in behavior, 3- physical dysfunctions (including reproduction dysfunctions), 4- physical deformities or dysplasias, 5- death and 6cancer or tumors/neoplasms. Sindermann (1990) defined disease as "any departure from the normal structure and functioning of an animal" or as "the end result of the interaction between a noxious stimulus and a biological system" and emphasized that a disease is a complex interaction between the host, the pathogen and the environment.

Flores-Lopes et al. (2001) also pointed out that the occurrence of this type of alteration with an identical pattern in bone plates is evidence of the presence of pollutants and/or degraded habitats and the analysis of the spatial and temporal variation of their occurrence frequency represents an important source of evaluation and water quality monitoring. Flores-Lopes et al. (2019) opined that the types of histopathological changes and the high frequency of severe changes indicate that individuals are exposed to a stressor in the environment. The occurrence of this type of alteration demonstrates that the water quality of the environments are undergoing important changes in its composition, being influenced by the presence of several types of polluting substances, that will cause a number of alterations in various species.

Epithelial cell lifting, epithelial hypertrophy and hyperplasia, slight deformations of the lamellae and fusion of adjacent lamellae were more prevalent and pronounced in the fish and mucous can be found on the respiratory epithelium of fish exposed to stress conditions, which can suggest that the mucous layer protects lamellar surfaces against infectious agents, toxic agents and particles in supension (Vasanthi et al., 2013). Liver and gill are more often recommended as environmental indicator organs of water pollution than other fish organs. Relatively high concentrations of heavy metals were found in liver and gill which suggests the possibility of using these two organs as metal bio-indicators present in the environment.

Figueiredo-Fernandes et al. (2007) observed that hyperplasia and fusion of secondary lamellae are defense mechanisms for species because they increase the area through which the water pollutants are able to reach the blood circulation. Gharred et al. (2015) reported that several molecular, biochemical and physiological processes may intercept the toxic effects of pollutants. The chronic exposure of fishes to contaminants may cause cellular process dysfunctions and tissue lesions.

Flores-Lopes et al. (2019) reported that histological analyses have revealed that changes usually occur along with other modifications, such as rectilineation of sinusoidal vessels, cells with cytoplasmic degeneration, constant presence of lymphocytes and macrophages and congestion of sinusoidal vessels. These alterations integrate the impact of a variety of stressors (pathogens, toxic compounds and unfavorable nutritional and environmental conditions). Thereby, histopathological biomarkers incorporate biotic factors and water quality in a holistic view of fish status, and are reliable 
markers of environmental stress (Zimmerliet al. 2007).

The presence of heavy metals, pesticides and other harmful chemicals, the liquid wastes and even half burnt bodies are producing deleterious effects on various biological systems, specially lymphatic system, of the aquatic organisms (Khan, 2016). Due to feeding and living in the aquatic environments fish are particularly vulnerable and highly exposed to pollution because they cannot escape from the detrimental effects of pollution (Mahboob et al., 2014).

Vazzana et al. (2014) reported that specific types of exposure affects leukocyte levels circulating in tissues and promotes leukocyte chromatin condensation, resulting in apoptosis, fragmentation in the DNA and death of these cells in long term exposures. According to Authman et al. (2015), heavy metals such as mercury, cadmium, copper, lead and zinc are of the most important pollutants which affect aquatic environment and fish. Rodrigues et al. (2018) did not observe significant histopathological changes in the intestine of the species Danio rerio in the acute experiment, however, there was a tendency for increased histological changes as $\mathrm{MnCl}_{2}$ concentrations increased.

Lamas et al. (2007) reported several specific advantages in describing the natural characteristics of aquatic systems and in assessing changes to habitats. According to Garred et al. (2015), the pollutants deeply affect the antioxidant/poxidant balance leading to the accumulation of reactive oxygen species (ROS), which affects the antioxidative enzymes. They observed that fishes under contamination stress are susceptible to the effects of ROS and have developed effective antioxidant defenses. According to these autors, the gills are considered an important uptake, bioconcentration and excretion of chemical compounds route and a prime target to contaminants, due to the surface area in contact with the external medium and reduced distance between internal and external medium.

Paiva et al. (2017) demonstrated histopathological changes in fish species after exposure to herbicide (Atrazine - ATZ). Nogueira et al. (2012) considered that with the increase in indiscriminate use of herbicides, high concentrations of these products have already been detected in Brazilian rivers. Abdel-Moneim et al. (2012) consider that due to urban, industrial and agricultural activities, freshwater sources are dumped with different kinds of chemicals that affect the inhabiting biota.

Paiva et al. (2017) reinforce the importance of the application of a semiquantitative methodology to evaluate the actual degree of severity induced by a xenobiotic in every analyzed target organ. For these authors, the results demonstrate that the liver is a sensitive histological biomarker. According to Thomas (1990), the advantage of using specific biochemical bioindicators is that they can often indicate the nature of the environmental stressor.

The data obtained in several studies using histopathological analysis by several investigators such as Malabarba et al. (1997), Flores-Lopes (2000), Flores-Lopes and Malabarba (2007), Flores-Lopes and Thomas, (2011), Flores-Lopes et al. (2001, 2002, 2005, 2019 and 2020) and Schulz and MartinsJunior (2001) demonstrate that the meaning and, mainly, the importance of using the 
histopathological method as a form of environmental assessment, demonstrating the different types of tissue changes that can occur due to the action of various types of chemical substances present in the environment.

\section{Conclusion}

This work aimed to verify the meaning and importance of using the histological method and, consequently, the results obtained through the histopathological analysis of the tissues of fish species in different environments, with a literature review of several scientific articles on the use this method.

The results obtained demonstrated the occurrence of several types of histopathological alterations due to the action of several types of chemical substances, called "Stressing Agents", which are present in different environments. The data from these studies make clear the importance of using the histological method as an excellent evaluator of organs and tissues of different species exposed to the action of different types of stressors.

These studies have shown that histopathological analysis is of fundamental importance in evaluating the occurrence of various types of changes, mainly those generated by the action of several products present in the environment. Through the studies we carried out, in different ecosystems, it was possible to observe that the presence of these substances can provoke several types of alterations.

The literature review allowed a verification that the occurrence of histopathological changes are not occasional, since they occur due to the presence of several stressors in the environment.

\section{References}

Abdel-Moneim A M, Al-Kahtani MA and Elmenshawy OM. (2012) Histopathological biomarkers in gills and liver of Oreochromis niloticus from polluted wetland environments, Saudi Arabia. Chemosphere 88: 1028-1035.

Abbas H H and Ali F. (2007) Study the effect of hexavalent chromium on some biochemical, cytological and histopathological aspects of Orechromis spp. Fish. Pak J Biol Sci. 10: 3973-3982.

Adams SM. (1990) Status and use of biological indicators for evaluating the effects of stress on fish. Am Fisheries Soc Symp. 8: 1- 8.

$\mathrm{Au}$ DWT, Wu RSS, Zhou BS and Lam PKS. (1999) Relationship between ultrastructural changes and EROD activities in liver of fish exposed to Benzo[a]pyrene. Environ Pollu. 104: 235-247.

Authman MMN, Zaki MS, Khallaf EA and Abbas HH. (2015) Use of fish as bio-indicator of the effects of heavy metals pollution. J Aquacul Res Develop. 6:1-13.

Ballesteros ML, Durando PE, Nores ML. Díaz MP, Bistoni MA and Wunderlin DA. (2009) Endosulfan induces changes in spontaneous swimming activity and acetylcholinesterase activity of Jenynsia multidentata (Anablepidae, Cyprinodontiformes). Environ Pollu. 157: 1573-1580.

Banaee M, Sureda A, Mirvaghefi AR and Ahmadi K. (2013) Biochemical and histological changes in the liver tissue of rainbow trout (Oncorhynchus mykiss) exposed to sub-lethal concentrations of diazinon. Fish Physiol Biochem. 39: 489- 501.

Bassey OB. (2019) Histopathological and biochemical response of Chrysichthys nigrodigitatus to environmental stressors from two polluted lagoons, Southewest Nigeria. J Toxicol Risk Assess. 5: 5 -25.

Bergman H. (1985) Assessment protocols for the identification and quantification of injury to fishery resources. Progress Report, U.S. Department of Interior, Washington, p 364.

Bernet DH, Schmidt W, Meier P, Burkhardt-Holm and Wahli T. (1999) Histopathology in fish: proposal for a protocol to assess aquatic pollution. J Fish Dis. 22: 25-34.

Boudou A and Ribeyre F. (1989) Fundamental concepts in aquatic ecotoxicology. In: Aquatic Ecotoxicology Fundamental concepts and 
Methodologies. vol. 1, CRC Press, Inc. BocaRaton, Florida, p 332.

Cantanhêde SM, Medeiros AM, Ferreira JRC, Alves LMC, Ferreira FS, Cutrim MVJ, Santos DMS. (2014) Uso de biomarcador histopatológico em brânquias de Centropomusundecimalis (Bloch, 1972) na avaliação da qualidade da água do Parque Ecológico Laguna da Jansen, São Luís - MA. Arquivo Brasileiro de Medicina Veterinária e Zootecnia. 66: 593-601.

Chavan VR and Muley DV. (2014) Effect of heavy metals on liver and gill of fish Cirrhinus mrigala. Intern J Current Microbiol Applied Sci. 3: 277- 288.

Dalzochio T, Rodrigues GGP, Petry IE, Gehlen G and Silva LB. (2016) The use of biomarkers to assess the health of aquatic ecosystems in Brazil: a review. Intern Aquatic Res. 8: 283-298.

Facey DE, Blazer VS, Gasper MM and Turcotte CL. (2005) Using fish biomarkers to monitor improvements in environmental quality. J Aquatic Ani Hlth. 17: 263- 266.

Figueiredo-Fernandes A, Ferreira-Cardoso JV, GarciaSantos S, Monteiro SM, Carrola J, Matos P and Fontaínhas-Fernandes A. (2007) Histopathological changes in liver and gill epithelium of Nile, Oreochromis niloticus, exposed to waterborne copper. Pesquisa Veterinária Brasil. 27: 103-109.

Flores-Lopes F. (2000) Histologia das estruturas esqueléticas de Astyanax alburnus (Hensel, 1870), do lago Guaíba, RS, Brasil. Porto Alegre, Dissertação de Mestrado, Programa de Pós-Graduação em Biologia Animal, UFRGS, p 52.

Flores-Lopes F, Malabarba LR, Pereira EHL and da Silva JFP. (2001) Alterações histopatológicas em placas ósseas do peixe cascudo Rineloricaria strigilata (Hensel) (Teleostei, Loricariidae) e sua freqüência no lago Guaíba, Rio Grande do Sul, Brasil. Revista Brasileira de Zool. 18:699-709.

Flores-Lopes F, Malabarba LR, da Silva JFP and Pereira EHL. (2002) Histologia de deformidades vertebrais em Astyanax alburnus (Hensel, 1870) (Ostariophysi: Characidae) do lago Guaíba, Rio Grande do Sul, Brasil. Comunicação do Museu de Ciências e Tecnologia PUCRS, Sér. Zool. 15: 137- 155.

Flores-Lopes F, Cognato DP and Malabarba LR. (2005) Alterações histopatológicas observadas nas brânquias do lambari Astyanax jacuihensis (Linnaeus, 1758) (Teleostei: Characidae) sob influência de efluentes petroquímicos. Revista Brasileira de Toxicol. 18: 99- 104.
Flores-Lopes F and Malabarba LR. (2007) Alterações histopatológicas observadas no fígado do lambaríAstyanax jacuhiensis (cope, 1894) (Teleostei, Characidae) sob influência de efluentes petroquímicos. Biociências 15:166-172.

Flores-Lopes F and Thomaz AT. (2011) Histopathologic alterations observed in fish gills as a tool in environmental monitoring. Brazilian J Biol. 71: $179-188$.

Flores-Lopes F and Reuss Strenzel GM. (2011) Frequency of morphological alterations in the fish of Lake Guaíbaand its application to environmental monitoring. Bioikos 25: 11- 23.

Flores-Lopes F. (2014) The occurrence of black spot disease in Astyanax aff. fasciatus (characiformes: characidae) in the Guaíba Lake basin, RS, Brazil. Brazilian J Biol. 74: 127-134.

Flores-Lopes F, Brito N. C, Cruz AO and Paulo DV. (2019) Histopathology of fish liver to assess the water quality of Limoeiro Stream, Floresta Azul, Ba, Brazil. Intern J Zool Invest. 5: 31- 42.

Flores-Lopes F, Correia MA and Silva DML. (2020) Histological and ultrastructural analysis of Tilapia rendalli liver as an environmental assessment tool for Cachoeira river, Bahia, Brazil. Intern J Zool Invest. 6: 31- 48.

Gharred T, Naija A, Bouali RR, Haouas Z and Chénais B. (2015) Assessment of oxidative stress and histopathological biomarkers in the Parablennius incognitus fish as potential contamination indicators of the Bay of Sousse (Tunisia). J Marine Sci: Res Develop. 5: 2- 8.

Gonzalez G, Crespo S and Brusle J. (1993) Histo-cytological study of the liver of the cabrilla sea bass, Serranus cabrilla (Teleostei, Serranidae), an available model for marine fish experimental studies. Fish Biol. 43: 363- 373.

Jenkins JA. (2004) Fish bioindicators of ecosystem condition at the Calcasieu Estuary, Lousiana. USGS Open-File Report, p 47.

Karr JR. (1981) Assessment of biotic integrity using fish communities. Fisheries 6: 21-27.

Khan SK. (2016) Histopathological changes in the spleen of Cyprinus carpio on acute exposure of copper sulphate. Intern J Adv Res. 4: 2249- 2255.

Kim S, Lochmiller RL, Stair EL, Lish JW, Rafferty DP and Qualls CWJr. (2001) Efficacy of histopathology in detecting petrochemical-induced toxicity in wild cotton rats (Sigmodon hispidus). Environ Pollu. 113: 323-329. 
Kinne O. (1984) Diseases of marine animals. Introduction, Pisces. Volume IV, Part 1, Biologische Anstalt Helgoland, Hamburg, Federal Republic of Germany. p 541.

Lamas S, Fernándes JA, Aboal JR and Carbalheira A. (2007) Testing the use of juvenile Salmo trutta L. as biomonitors of heavy metal pollution in freshwater. Chemosphere 67: 221-228.

Mahboob S, Al-Balawi HFA, Al-Misned F, Al-Quraishy. S and Ahmad Z. (2014) Tissue metal distribution and risk assessment for important fish species from Saudi Arabia. Bull Environ Contam Toxicol. 92: 61- 66.

Malabarba LR, Pereira EHL, Silva JF.P and Bruschi JRW. (1996) Monitoramento biológico de águas superficiais através da freqüência de anomalias morfológicas em populações naturais de peixes: estudo do caso do rio Guaíba. Relatório Técnico, Riocell, Guaíba, RS.

Malabarba LR, Pereira EHL and Silva JF.P. (1997) Monitoramento da freqüência de anomalias morfológicas em Astyanax alburnusno rio Guaíba (análises 1993-1997). Relatório Técnico, Riocell, Guaíba, RS.

Malins DC. (1989) The use of environmental assays for impact assessment. Hydrobiol. 188/189: 87- 91.

Mccain BB, Brown DW, Krahn MM, Myers MS, Chan SL and Malins DC. (1988) Marine pollution problems, North American West Coast. Aquatic Toxicol. 11: 143- 162.

Mendil D, Demirci Z, Tuzen M and Soylak M. (2010) Seasonal investigation of trace element contents I: commercially valuable fish species from the Black sea, Turkey. Food Chemical Toxicol. 48: 865-870.

Möller H. (1985) A critical review of the role of pollution as cause of fish diseases. In: Fish and Shellfish Pathology. A. E. Ellis (ed.), Academic Press, London, pp. 169-182.

Moore MN. (1985) Cellular responses to pollutants. Marine Pollut Bull. 16: 134- 139.

Moore MN and Simpson MG. (1992) Molecular and cellular pathology in environmental impact assessment. Aquatic Toxicol. 22: 313- 322.

Morado CN, Araújo FG and Gomes I.D. (2017) The use of biomarkers for assessing effects of pollutant stress on fish species from a tropical river in Southeastern Brazil. Acta Scientiarum 39: 431- 439.

Nogueira EM, Dores EFGC, Pinto AA, Amorim RSS, Ribeiro ML and Lourencetti C. (2012) Currently used pesticides in water matrices in CentralWestern Brazil. J Brazilian Chem Soc. 23:1476-1487.

Oliveira Ribeiro CAde, Belger L, Pelletier É and Rouleau C. (2002) Histopathological evidence of inorganic mercury and methyl mercury toxicity in the arctic charr (Salvelinus alpinus). Environ Res. 90: 217-225.

Paiva PP, Delcorso MC, Matheus VA, Queiroz SCN, Collares-Buzato CB and Arana S. (2017) Acute toxicity of commercial atrazine in Piaractus mesopotamicus: Histopathological, ultrastructural, molecular, and genotoxic evaluation. Vet World 10: 1008-1019.

Paulo DV, Fontes FM and Lopes F.F.. (2012) Histopathological alterations observed in the liver of Poecilia vivípara (Cyprinodontiformes: Poeciliidae) as a tool for the environmental quality assessment of the Cachoeira River, BA. Brazilian J Biol. 72: 131-140.

Paulo DV, Lopes LL, Neves AOC, Júnior FOM, Jesus RM, Braga LGT and Flores-Lopes F. (2020) Bioaccumulation, hepatotoxicity, immune response and growth in Oreochromis niloticus exposed to cadmium. Intern J Zool Invest. 6: 1- 20.

Poleksic V, Lenhardt M, Jaric I, Djordjevic D, Gacic Z, Cvijanovic G and Raskovic B. (2010) Liver, gills and skin histopathology and heavy metal content of the Danube starlet (Acipenser rutheneus Linnaeus, 1758). Environ Toxicol Chem. 29: 515- 521.

Rodrigues GZP, Souza MS, Silva AH, Zwetsch BG and Gehlen G. (2018) Evaluation of intestinal histological damage in zebrafish exposed to environmentally relevant concentrations of manganese. Ciência e Natura 40: e52.

Schulz UH and Martins-Junior H. (2001) Astyanax fasciatus as bioindicators of water pollution of rio dos Sinos, RS, Brazil. Brazilian J Biol. 61: 615-622.

Sindermann CJ. (1990) Principal diseases of marine fish and shellfish. 2nd Ed., Academic Press, London, Vol. 1, p 521.

Sureda A, Box A, Tejada S, Blanco A, Caixach J and Deudoro S. (2011) Biochemical responses of Mytilus galloprovincialis as biomarkers of acute environmental pollution caused by the Don Pedro oil spill (Elvissa Island, Spain). Aquatic Toxicol. 101: 540- 549.

Teh SJ, Adams SM and Hinton DE. (1997) Histopathologic biomarkers in feral Freshwater fish populations exposed to different types of contaminant stress. Aquatic Toxicol. 37: 51-70. 
Thomas P. (1990) Molecular and biochemical responses of fish to stressors and their potential use in environmental monitoring. Am Fisheries Soc Symp. 8: 9-28.

Thophon S, Kruatrachue M, Upatham ES, Pokethitiyook P, Sahaphong S and Jaritkhuan S. (2003) Histological alterations of white seabass, Lates calcarifer, in acute and subchronic cadmium exposure. Environ Pollut. 121: 307-320.

Vasanthi LA, Revathi P, Mini J and Munuswamy N. (2013) Integrated use of histological and ultrastructural biomarkers in Mugil cephalus for assessing heavy metal pollution in Ennore estuary, Chennai. Chemosphere 91: 1156-1164.

Vazzana M, Celi M, Tramati C, Ferrantelli V, Arizza V and Parrinello N. (2014) In vitro effect of cadmium and copper on separated blood leukocytes of Dicentrarchus labrax. Ecotoxicol Environ Safety 102: 113- 120.
Walters GR and Plumb JA. (1980) Environmental stress and bacterial infection in channel catfish, Ictalurus punctatus Rafinesque. J Fish Biol. 17: 177- 185.

Wedemeyer GA and Mcleay DJ. (1981) Methods for determining the tolerance of fishes to environmental stressors. In: Stress and Fish, A. Pickering (ed.), Academic Press., London, p. 247- 268.

Zimmerli S, Bernet D, Burkhardt-Holm P, SchmidtPosthaus H, Vonlanthen P, Wahli T and Segner $\mathrm{H}$. (2007) Assessment of fish health status in four Swiss rivers showing a decline of brown trout catches. Aquatic Sci. 69: 11- 25. 